\title{
ВНЕШНИЙ ВОДООБМЕН В ПОЛЕЗНОМ ОБЪЕМЕ СРЕДНЕДНЕПРОВСКОГО ВОДОХРАНИЛИЩА В ПРОЕКТНЫХ И ЕГО СОВРЕМЕННЫХ ПАРАМЕТРАХ
}

\author{
Е.В. Обухов, докт. экон. наук, канд. техн. наук, професор, акад. МАНЭБ, УО (Одесса) \\ 65039, ул. Среднефонтанская, 30а, г. Одесса, Украина.
}

Проблемой водохранилищ в настоящее время является их функиионирование в условиях изменяющегося климата. Управление водными ресурсами водных объектов, оченка состояния и происходящих в них процессов требуют постоянного мониторинга и анализа. Цель работы - исследование интенсивности внешнего водообмена на Среднеднепровском водохранилище, горизонтальной и вертикальной составляющих водообмена, а также хозяйственного использования объекта. На основе водобалансовых составляющих исследована интенсивность внешнего водообмена в полезном объеме водохранилища в проектных и его современных параметрах с учетом водности года за весь период эксплуатации: многоводный 1970 г., маловодный 1972 г. и очень маловодный 2015 г. Определены коэффициенты интенсивности и показатели внешнего водообмена по каждому месяиу года, месяиы с максимальной и минимальной интенсивностями внешнего водообмена во временных единицах и основной фактор влияния на него - боковая приточность в водохранилище. Максимальная интенсивность внешнего водообмена в водохранилище в очень маловодном году в весенний и осенний периоды эксплуатации ухудшилась по отношению к многоводному году в четыре раза. Установлено, что чем больше коэффициент интенсивности внешнего водообмена, тем меньше показатель внешнего водообмена во временных единицах и интенсивнее происходят смена и самоочищение воды в водохранилище. Если показатель внешнего водообмена меньше единиць, то смена нормативных водных ресурсов водохранилища будет происходить меньше чем за год. Результаты исследований могут быть полезныли при разработке режимов эксплуатачии водохранилища в условиях изменения климата. Библ. 4, табл. 1, рис. 5

Ключевые слова: водохранилище, водный баланс, водообмен, интенсивность, коэффищиент.

\section{EXTERNAL WATER EXCHANGE IN USEFUL VOLUM MIDDLEDNIEPER RESERVOIR IN THE PROJECT AND ABOUT ITS PARAMETERS}

\author{
E. Obukhov, doctor of economic sciences, candidate of technical sciences, professor, academician of IAEMLPS, \\ Ukraine Department
}

65039, 30a Srednefontanskaya St., Odessa, Ukraine.

A curren t problem of reservoirs is their functioning in conditions of a changing climate. In such conditions, water resources management of water bodies as well as assessment their state and ongoing processes require permanent monitoring and analysis. The aim of the author of the present work was to study the intensity of external water exchange of the Middlednieper (Dneprodzerzhinsk) reservoir, the horizontal and vertical components of the water cycle and the economic use of the water body. On the basis of water balance components, the intensity of external water exchange in the useful volume of the reservoir in its design and modern parameters is studied, taking into account the water content of the year for the entire period of its operation: high-water 1970, low-water 1972 and very low-water 2015.

Intensity factors and indicators of external water exchange for each month of the year, and for the months of the maximum and minimum intensity of the external water exchange during a unit of time, as well as the main factor influencing on the water exchange, viz. the lateral inflow in the reservoir have been determined. The maximum intensity of the external water exchange in the reservoir during a very dry year has deteriorated in the spring and autumn periods of its operation fourfold as compared with the one of the high-water year. It is determined that the higher the intensity of the external water exchange is, the less the indicator of the external water exchange during a unit of time is and the more intensively an exchange and self-purification of the water in the reservoir are being fulfilled. If the rate of external water exchange is less than one, then the shift of regulatory water resources of the reservoir will take place in less than a year. The results of the study can be useful in developing modes of reservoir operation in conditions of a climate change. Ref. 4, tabl. 1, fig. 5.

Keywords: water reservoir, water balance, water exchange, intensity, ratio 


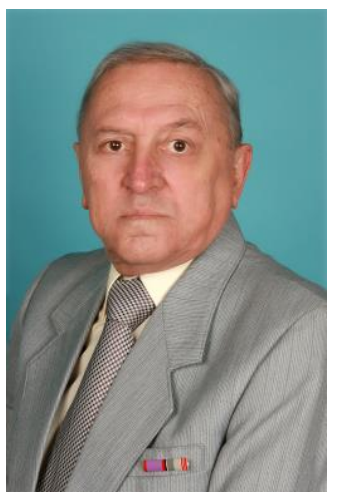

E.В. Обухов

E. Obukhov
Сведения об авторе: доктор экономических наук, кандидат технических наук, профессор, академик МАНЭБ, УО, Одесса. Образование: Одесский инженерностроительный институт, инженергидротехник, специальность «Гидротехническое строительство речных сооружений и гидроэлектростанций.

Научная сфера: Технико-экономикоэкологические проблемы в гидроэнергетике Публикации: 235, 8 монографий.

ORCID: 0000-0002-0726 -5736

Контакты: тел./факс: +38-048-776-1-885

e-mail: ev.obukhov@googlemail.com
Author information: Doctor of economics, candidate of technical Sciences, professor, academician of IAEMLPS, Ukraine Department, Odessa.

Education: Odessa Civil Engineering institute, engineer-hydraulics, specialty "Hydraulic engineering of river structures and hydroelectric power plants"

Research area: Technical-economicenvironmental problemin hydropower. Publications: 235, 8 monographs. ORCID: 0000-0002-0726-5736 Contacts: phone/fax: +38-048-776-1-885 e-mail: ev.obukhov@googlemail.com
Перечень используемых обозначений и сокращений:

ГЭС - гидроэлектростанция;

НПУ - нормальный подпертый уровень;

WII - проектный полный объем водохранилища;

Wк - проектный полезный объем водохранилища;

Введение и постановка проблемы. Проблемой водохранилищ является их функционирование в условиях изменяющегося климата и изменения их параметров в процессе продолжительной эксплуатации.

Интенсивность водообмена в водохранилищах являются одной из важнейших характеристик их состояния [1-4]. Взаимодействие гидрологических и гидродинамических процессов влияет на внешний и внутренний водообмен, на содержание растворенных веществ в водоемах, на качество воды, на интенсивность цветения воды в водохранилищах степной зоны при накоплении в них химических или биологических веществ. Целью данной работы является исследование интенсивности внешнего водообмена в полезном объеме Среднеднепровского водохранилища в проектных и его современных параметрах с учетом водности года зксплуатации, горизонтальной и вертикальной составляющих водообмена, а также его хозяйственного использования и сопоставление полученных результатов с рассчитанными ранее аналогичными показателями для помесячно заполненного водохранилища с учетом его мертвого объема [3].

Основными исходными материалами для исследования являются реальные водобалансовые показатели по Среднеднепровскому водохранилищу за многоводный (1970 г. с объемом годового руслового притока 75,55 км ${ }^{3}$, маловодный
Wк*- современный полезный объем водохранилища;

МВт - мегаватт;

кВт·ч - киловатт-час.

$\left(1972\right.$ г. - 32,67 км $\left.{ }^{3}\right)$ и очень маловодный (2015 г. - 19,5 км ${ }^{3}$ ) года.

Среднеднепровское водохранилище - четвертая ступень в составе Днепровского каскада, на которой осуществляется суточное и недельное регулирование стока.

Среднеднепровское водохранилище расположено на территории Кировоградской, Полтавской и Днепропетровской областей. Площадь водосбора - 434000 км². Среднемноголетний сток $52 \mathrm{kм}^{3}$. Проектная установленная мощность ГЭС - 352 МВт, среднегодовая выработка электроэнергии -1250 млн. кВт·ч.

Проектные полная и полезная емкость водохранилища, соответственно, 2,40 и 0,3 км³. Его площадь при отметке нормального подпертого уровня - 567 км $^{2}$, при уровне мертвого объема 471 км² $^{2}$ Длина водохранилища 149 км, максимальная ширина -8 км, средняя ширина $-5,1$ км, максимальная глубина $-16,1$ м, средняя $-4,3$ м. Площадь мелководий водохранилища -182 км² $^{2}$ Максимальный статический напор - 15,5 м, минимальный - 8,4 м, расчетный - 9,85 м. Расчетный расход водосбросной плотины - $20100 \mathrm{~m}^{3} / \mathrm{c}$. Расчетный максимальный сбросной расход через сооружения $(p=0,1 \%)-23300 \mathrm{~m}^{3} / \mathrm{c}$.

После начала реконструкции установленная мощность ГЕС составляет 388 МВт [2], а выработка электроэнергии за 2018 год - 1197,443 млн кВт·ч.

Современные площадь Среднеднепровско- 


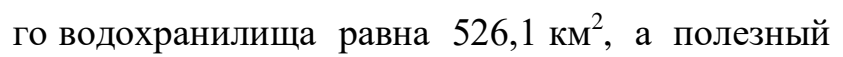
объем его $0,25 \mathrm{kм}^{3}$ [1].

Результаты исследований и их обсуждение Интенсивность внешнего водообмена водохранилища включают как горизонтальную, так и вертикальную составляющие. К горизонтальным составляющим внешнего водообмена относят приток воды в водохранилище (по основной реке и боковой), а также сток из водохранилища через гидроузел.

Одна из вертикальных составляющих внешнего водообмена учитывает выпадение атмосферных осадков на водную поверхность водохранилища, а также испарение с его поверхности. Эта составляющая иногда существенно влияет на показатели внешнего водообмена во внутригодовом аспекте. При оценке внешнего водообмена предлагается также во внутригодовом аспекте учитывать и другие составляющие водного баланса водоема - сброс в водохранилище сточных и бытовых вод, забор воды на хозяйственные нужды.

Используя изложенную в [3] методику, по формулам Штефана В.Н., Литвинова А.С., Калинина Г.П. и Караушева А.В. и рекомендации [4] были рассчитаны коэффициенты интенсивности Кв и показатели внешнего водообмена Ту для заполненного (рис. 1) и полезного объема Среднеднепровского водохранилища в характерные по водности годы (табл. 1 и рис.2-5).

Таблица 1. Показатели внешнего водообмена Среднеднепровского водохранилища.

Table 1. Indicators foreign exchange Middlednieper reservoir.

\begin{tabular}{|c|c|c|c|c|c|c|c|c|c|c|c|}
\hline $\begin{array}{l}\text { Мe- } \\
\text { сяц }\end{array}$ & $\boldsymbol{K}_{\boldsymbol{B}} \boldsymbol{1}$ & $\begin{array}{c}\boldsymbol{T} y_{1} \\
\text { лет }\end{array}$ & $K_{\boldsymbol{B}_{2}}$ & $\begin{array}{c}\boldsymbol{T} \boldsymbol{y}_{2} \\
\text { лem }\end{array}$ & 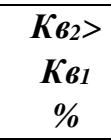 & $\kappa \boldsymbol{B}_{3}$ & $\begin{array}{c}T y_{3} \\
\text { леm }\end{array}$ & $\begin{array}{c}K \boldsymbol{b}_{3}> \\
\boldsymbol{K} \boldsymbol{b}_{1} \\
\%\end{array}$ & $K_{\boldsymbol{B} 4}$ & $\begin{array}{c}K_{64}> \\
K_{B_{1}} \\
\%\end{array}$ & $\begin{array}{r}\boldsymbol{T y}_{4} \\
\text { лет }\end{array}$ \\
\hline \multicolumn{12}{|c|}{ Многоводный 1970 год } \\
\hline I & 12,54 & 0,080 & 12,76 & 0,078 & 1,70 & 12,81 & 0,078 & 2,09 & 12,82 & 2,19 & 0,078 \\
\hline II & 9,77 & 0,102 & 9,93 & 0,100 & 1,64 & 9,98 & 0,100 & 2,08 & 9,99 & 2,19 & 0,100 \\
\hline III & 18,12 & 0,055 & 19,57 & 0,051 & 7,44 & 19,61 & 0,051 & 7,64 & 19,63 & 7,70 & 0,051 \\
\hline IV & 33,41 & $\mathbf{0 , 0 3 0}$ & 36,00 & $\mathbf{0 , 0 2 8}$ & 7,20 & 36,02 & $\mathbf{0 , 0 2 8}$ & 7,26 & 36,03 & 7,29 & $\mathbf{0 , 0 2 8}$ \\
\hline $\mathrm{V}$ & 32,17 & 0,031 & 32,60 & 0,031 & 1,32 & 32,69 & 0,031 & 1,59 & 32,70 & 1,62 & 0,031 \\
\hline VI & 14,78 & 0,068 & 14,95 & 0,067 & 1,12 & 15,05 & 0,066 & 1,81 & 15,06 & 1,88 & 0,066 \\
\hline VII & 9,57 & 0,104 & 9,71 & 0,103 & 1,45 & 9,86 & 0,101 & 2,98 & 9,87 & 3,11 & 0,101 \\
\hline VIII & 9,08 & $\mathbf{0 , 1 1 0}$ & 9,23 & 0,108 & 1,61 & 9,46 & 0,106 & 4,08 & 9,48 & 4,26 & $\mathbf{0 , 1 0 5}$ \\
\hline IX & 12,88 & 0,078 & 13,09 & 0,076 & 1,59 & 13,22 & 0,076 & 2,56 & 13,24 & 2,70 & 0,075 \\
\hline $\mathrm{X}$ & 12,55 & 0,080 & 13,19 & 0,076 & 4,81 & 13,38 & 0,075 & 6,16 & 13,40 & 6,33 & 0,074 \\
\hline $\mathrm{XI}$ & 10,72 & 0,093 & 11,08 & 0,090 & 3,16 & 11,10 & 0,090 & 3,38 & 11,11 & 3,49 & 0,090 \\
\hline XII & 13,90 & 0.072 & 14,10 & 0.071 & 1.39 & 14,14 & 0.071 & 1.65 & 14,15 & 1.73 & 0.070 \\
\hline \multicolumn{12}{|c|}{ Маловодный 1972 год } \\
\hline I & 11,34 & $\begin{array}{l}0,088 \\
\end{array}$ & 11,44 & 0,087 & 0,87 & 11,45 & 0,087 & 0,96 & 11,46 & 1,05 & $\mathbf{0 , 0 8 7}$ \\
\hline II & 9,60 & 0,104 & 9,65 & 0,104 & 0,52 & 9,65 & 0,104 & 0,52 & 9,66 & 0,63 & 0,103 \\
\hline III & 4,01 & 0,249 & 4,12 & 0,243 & 2,64 & 4,16 & 0,241 & $\mathbf{3 , 5 3}$ & 4,17 & $\mathbf{3 , 8 3}$ & 0,240 \\
\hline IV & 5,07 & 0,197 & 5,49 & 0,182 & 7,65 & 5,53 & 0,181 & 8,35 & 5,54 & 8,59 & 0,180 \\
\hline $\mathrm{V}$ & 7,03 & 0,142 & 7,29 & 0,137 & 3,58 & 7,39 & 0,135 & 4,85 & 7,40 & 5,04 & 0,135 \\
\hline VI & 7,99 & 0,125 & 8,14 & 0,123 & 1,77 & 8,30 & 0,120 & 3,66 & 8,30 & 3,75 & 0,120 \\
\hline VII & 8,57 & 0,117 & 8,79 & 0,114 & 2,54 & 8,98 & 0,111 & 4,57 & 8,99 & 4,76 & 0,111 \\
\hline VIII & 9,93 & 0,100 & 10,06 & 0,099 & 1,26 & 10,29 & 0,097 & 3,41 & 10,31 & 3,69 & 0,097 \\
\hline IX & 8,58 & 0,116 & 8,65 & 0,115 & 0,80 & 8,83 & 0,113 & 2,83 & 8,85 & 3,02 & 0,113 \\
\hline$X$ & 7,61 & 0,131 & 7,73 & 0,129 & 1,51 & 7,81 & 0,128 & 2,49 & 7,82 & 2,68 & 0,128 \\
\hline XI & 8,15 & 0,123 & 8,38 & 0,119 & 2,75 & 8,45 & 0,118 & 3,51 & 8,46 & 3,70 & 0,118 \\
\hline XII & 10,84 & 0,092 & 11,12 & 0.090 & 2.49 & 11,14 & 0.090 & 2.65 & 11,16 & 2.81 & 0,090 \\
\hline \multicolumn{12}{|c|}{ Очень маловодный 2015 год } \\
\hline I & 6,156 & 0,162 & 6,289 & 0,159 & 2,13 & 6,318 & 0,158 & 2,56 & 6,346 & 3,00 & 0,157 \\
\hline II & 7,564 & $\mathbf{0 , 1 3 2}$ & $\mathbf{7 , 7 8 3}$ & $\mathbf{0 , 1 2 8}$ & 2,81 & $\mathbf{7 , 8 2 5}$ & $\mathbf{0 , 1 2 8}$ & 3,33 & $\mathbf{7 , 8 6 7}$ & 3,85 & $\mathbf{0 , 1 2 7}$ \\
\hline III & 5,960 & 0,167 & 6,324 & 0,158 & 5,76 & 6,414 & 0,156 & 7,07 & 6,458 & 7,71 & 0,155 \\
\hline
\end{tabular}




\begin{tabular}{|c|c|c|c|c|c|c|c|c|c|c|c|}
\hline $\begin{array}{l}\text { Мe- } \\
\text { сяц }\end{array}$ & $\boldsymbol{K} \boldsymbol{b} \boldsymbol{I}$ & $\begin{array}{c}T y_{I} \\
\text { лem }\end{array}$ & $K_{\boldsymbol{B}_{2}}$ & $\begin{array}{c}T y_{2} \\
\text { лem }\end{array}$ & $\begin{array}{c}K \boldsymbol{K}_{2}> \\
\boldsymbol{K} \boldsymbol{B}_{1} \\
\%\end{array}$ & $K_{\boldsymbol{B} 3}$ & $\begin{array}{r}T_{3} \\
\text { лет }\end{array}$ & $\begin{array}{c}K_{b 3}> \\
K_{b 1} \\
\%\end{array}$ & $\boldsymbol{K}_{\boldsymbol{B} 4}$ & $\begin{array}{c}\boldsymbol{K}_{\boldsymbol{B} 4}> \\
\boldsymbol{K} \boldsymbol{B} 1 \\
\boldsymbol{\%}\end{array}$ & $\begin{array}{c}T_{4} \\
\text { лem }\end{array}$ \\
\hline IV & 3,754 & 0,266 & 4,113 & 0,243 & 8,74 & 4,220 & 0,237 & 11,05 & 4,289 & 12,48 & 0,233 \\
\hline $\mathrm{V}$ & 4,975 & 0,201 & 5,200 & 0,192 & 4,32 & 5,304 & 0,188 & 6,21 & 5,357 & 7,12 & 0,187 \\
\hline VI & 3,639 & 0,275 & 3,750 & 0,267 & 2,97 & 3,959 & 0,252 & 8,26 & 4,000 & 9,04 & 0,250 \\
\hline VII & 5,281 & 0,189 & 5,374 & 0,186 & 1,74 & 5,494 & 0,182 & 3,88 & 5,521 & 4,35 & 0,181 \\
\hline VIII & 5,306 & 0,188 & 5,380 & 0,186 & 1,38 & 5,544 & 0,180 & 4,29 & 5,574 & 4,80 & 0,179 \\
\hline IX & 4,298 & 0,233 & 4,358 & 0,229 & 1,39 & 4,480 & 0,223 & 4,07 & 4,518 & 4,87 & 0,221 \\
\hline $\mathbf{X}$ & 3,342 & 0,299 & 3,434 & 0,291 & 2,70 & 3,506 & 0,285 & 4,68 & 3,548 & 5,83 & 0,282 \\
\hline XI & 3,845 & 0,260 & 3,945 & 0,253 & 2,53 & 4,005 & 0,250 & 3,99 & 4,038 & 4,78 & 0,248 \\
\hline XII & 5,325 & 0,188 & 5,462 & 0,183 & 2.51 & 5,495 & 0,182 & 3,09 & 5,534 & 3,78 & 0,181 \\
\hline \multicolumn{12}{|c|}{ Очень маловодный 2015 год* } \\
\hline I & 7,387 & 0,135 & 7,547 & 0,132 & 2,13 & 7,582 & 0,132 & 2,56 & 7,615 & 3,00 & 0,131 \\
\hline II & 9,077 & $\mathbf{0 , 1 1 0}$ & 9,340 & $\mathbf{0 , 1 0 7}$ & 2,81 & 9,390 & 0,106 & $\mathbf{3 , 3 3}$ & 9,441 & 3,85 & 0,106 \\
\hline III & 7,152 & 0,140 & 7,589 & 0,132 & 5,76 & 7,697 & 0,130 & 7,07 & 7,750 & 7,71 & 0,129 \\
\hline IV & 4,505 & 0,222 & 4,936 & 0,202 & 8,74 & 5,064 & 0,197 & 11,05 & 5,147 & 12,48 & 0,194 \\
\hline $\mathrm{V}$ & 5,970 & 0,167 & 6,240 & 0,160 & 4,32 & 6,365 & 0,157 & 6,21 & 6,429 & 7,12 & 0,155 \\
\hline VI & 4,367 & 0,229 & 4,500 & 0,222 & 2,97 & 4,751 & 0,210 & 8,26 & 4,800 & 9,04 & 0,208 \\
\hline VII & 6,337 & 0,158 & 6,449 & 0,155 & 1,74 & 6,593 & 0,152 & 3,88 & 6,625 & 4,35 & 0,151 \\
\hline VIII & 6,367 & 0,157 & 6,456 & 0,155 & 1,38 & 6,653 & 0,150 & 4,29 & 6,689 & 4,80 & 0,149 \\
\hline IX & 5,158 & 0,194 & 5,230 & 0,191 & 1,39 & 5,376 & 0,186 & 4,07 & 5,422 & 4,87 & 0,184 \\
\hline $\mathbf{X}$ & 4,010 & 0,249 & 4,121 & 0,243 & 2,70 & 4,207 & 0,238 & 4,68 & 4,258 & 5,83 & $\mathbf{0 , 2 3 5}$ \\
\hline XI & 4,614 & 0,217 & 4,734 & 0,211 & 2,53 & 4,806 & 0,208 & 3,99 & 4,846 & 4,78 & 0,206 \\
\hline XII & 6,390 & 0,156 & 6,555 & 0,153 & 2.51 & 6,594 & 0,152 & 3,09 & 6,641 & 3,78 & 0,151 \\
\hline
\end{tabular}

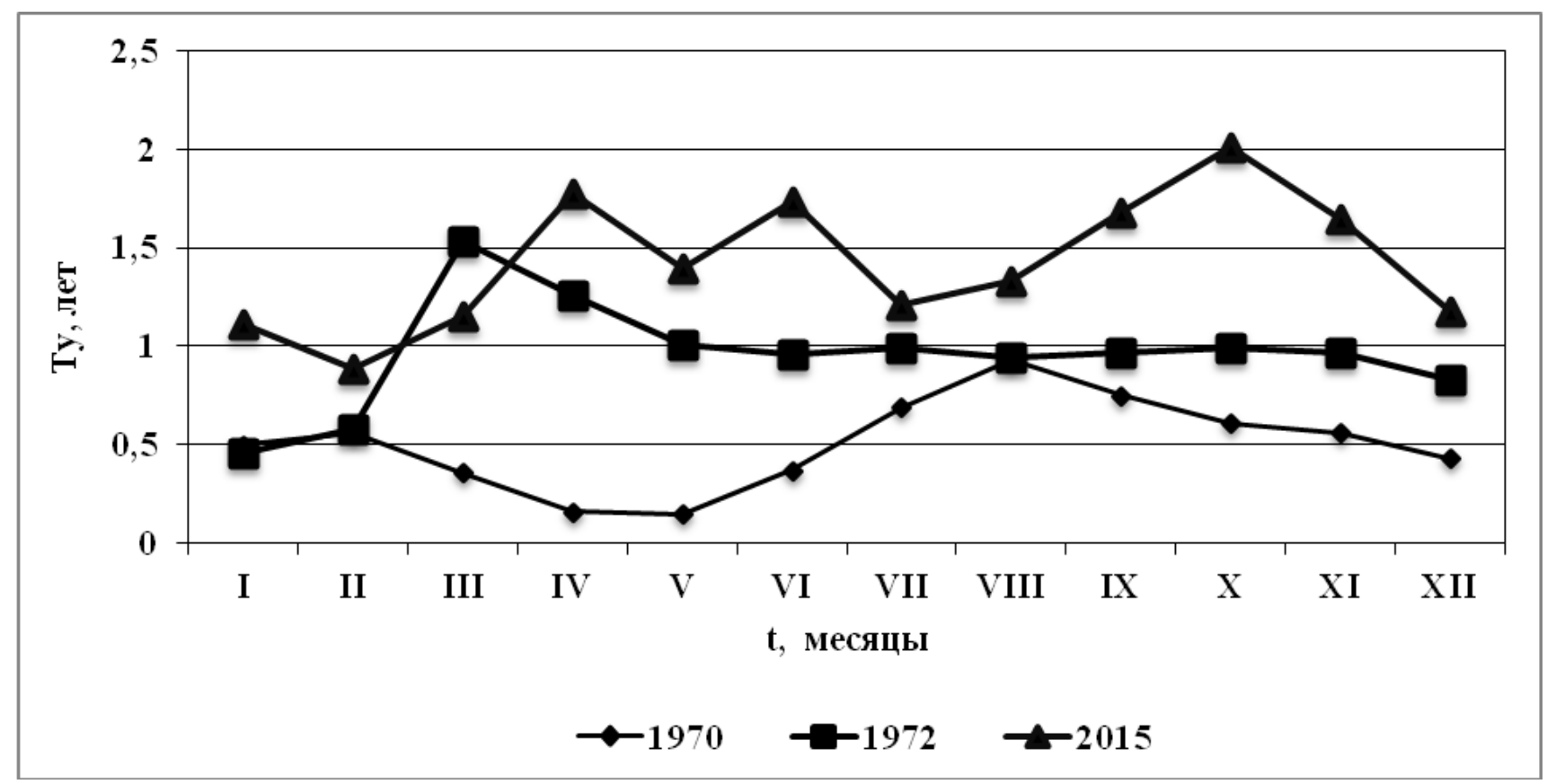

Рис. 1. График $\mathrm{Ty}=\mathrm{f}(\mathrm{t})$ показателей внешнего водообмена в заполненном Среднеднепровском водохранилище в проектных параметрах [3].

Fig. 1. Graph $\mathrm{Tu}=\mathrm{f}(\mathrm{t})$ indicators of external water exchange in the filled Middlednieper reservoir in the project settings [3]. 


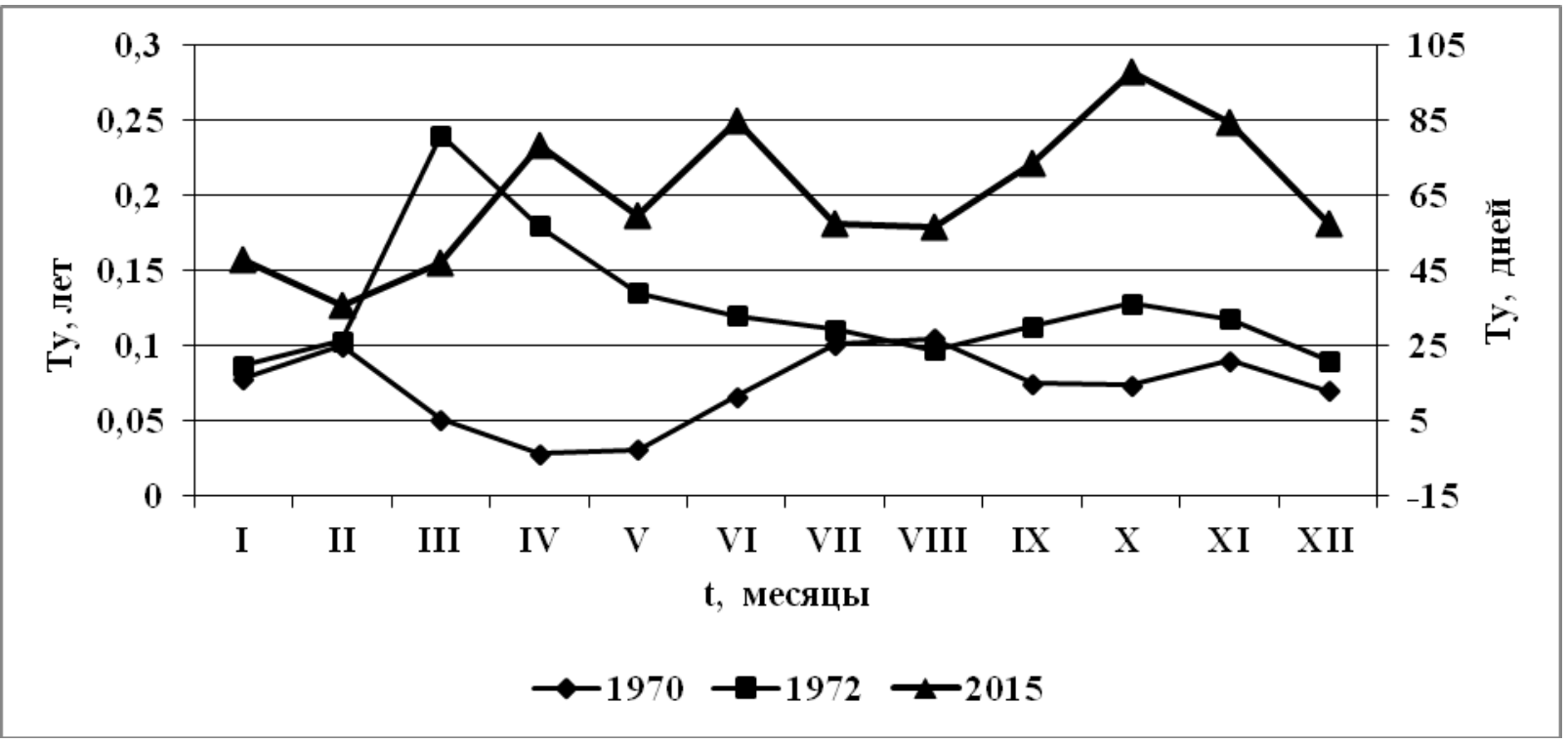

Рис. 2. График $\mathrm{Ty}=\mathrm{f}(\mathrm{t})$ показателей внешнего водообмена в полезном объеме Среднеднепровского водохранилища в проектных параметрах.

Fig. 2. Graph $\mathrm{Tu}=\mathrm{f}(\mathrm{t})$ indicators of external water exchange in useful volume Middlednieper reservoir in the project settings.

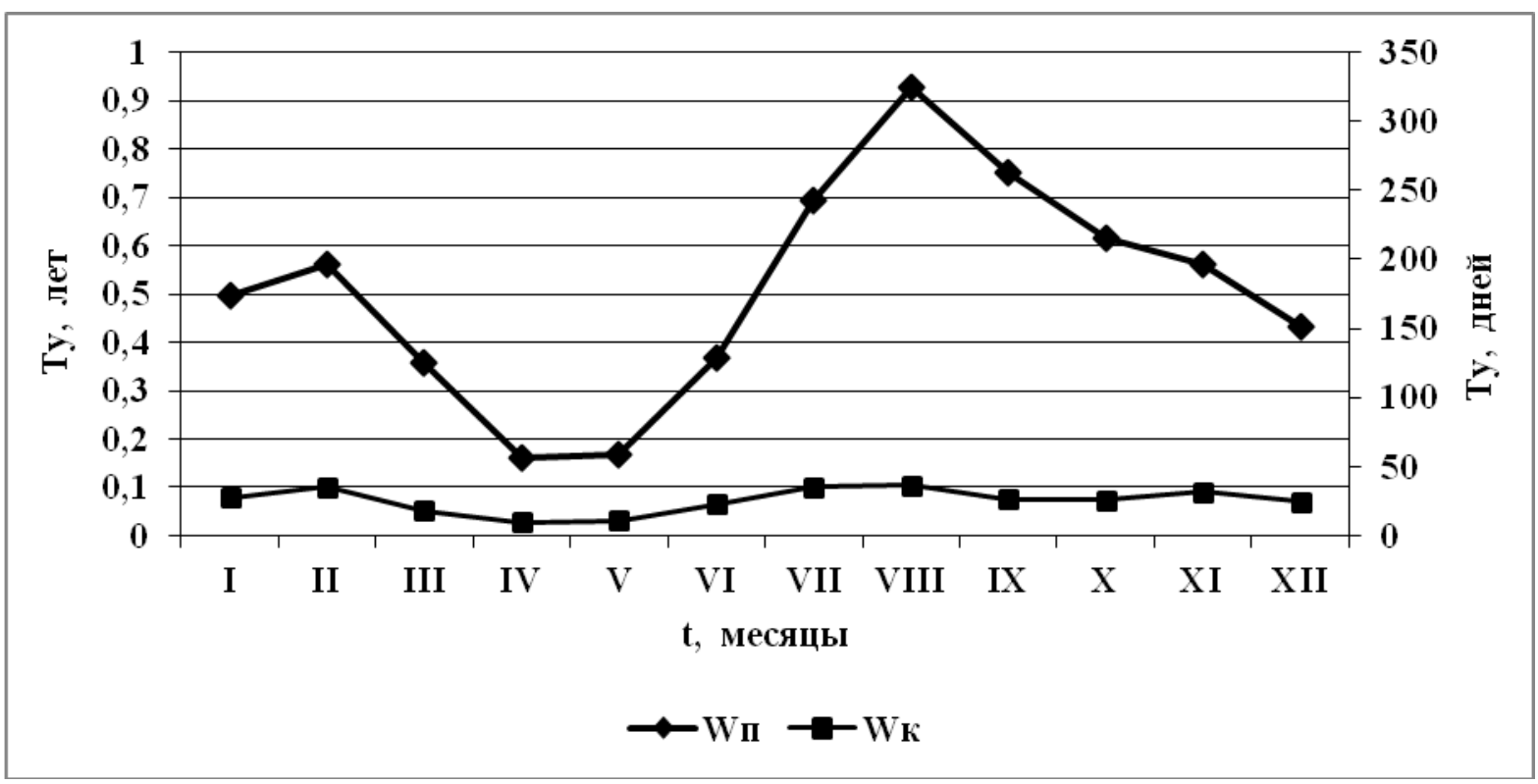

Рис. 3. График $\mathrm{Ty}=\mathrm{f}(\mathrm{t})$ показателей внешнего водообмена в Среднеднепровском водохранилище в многоводном 1970 году.

Fig. 3. Graph $\mathbf{T u}=\mathbf{f}(t)$ indicators of external water exchange in Middlednieper reservoir in low water 1970. 


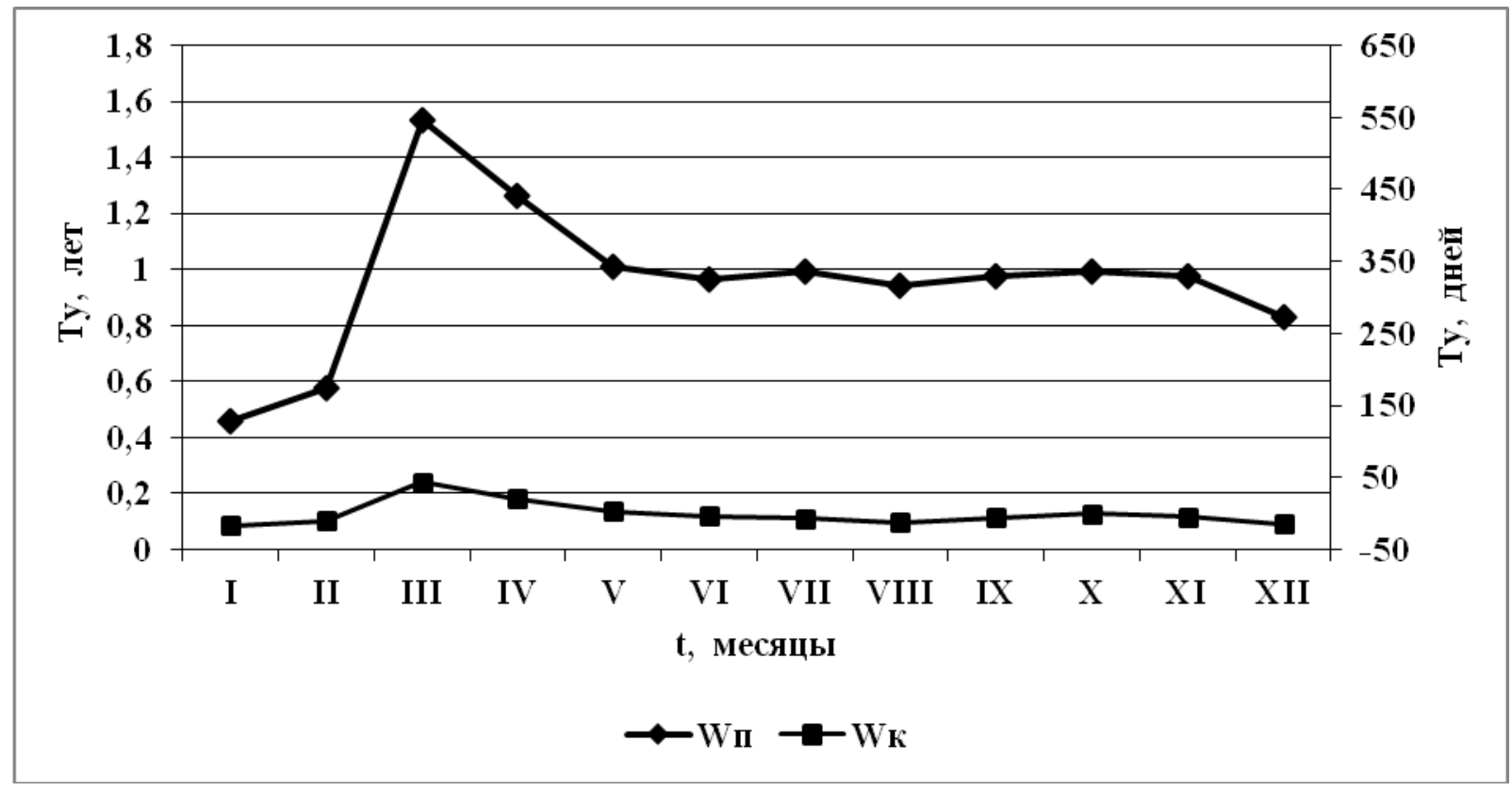

Рис. 4. График $\mathrm{Ty}=\mathrm{f}(\mathrm{t})$ показателей внешнего водообмена в Среднеднепровском водохранилище в маловодном 1972 году.

Fig. 4. Graph $\mathrm{Tu}=\mathrm{f}(\mathrm{t})$ indicators of external water exchange in Middlednieper reservoir in low water 1972.

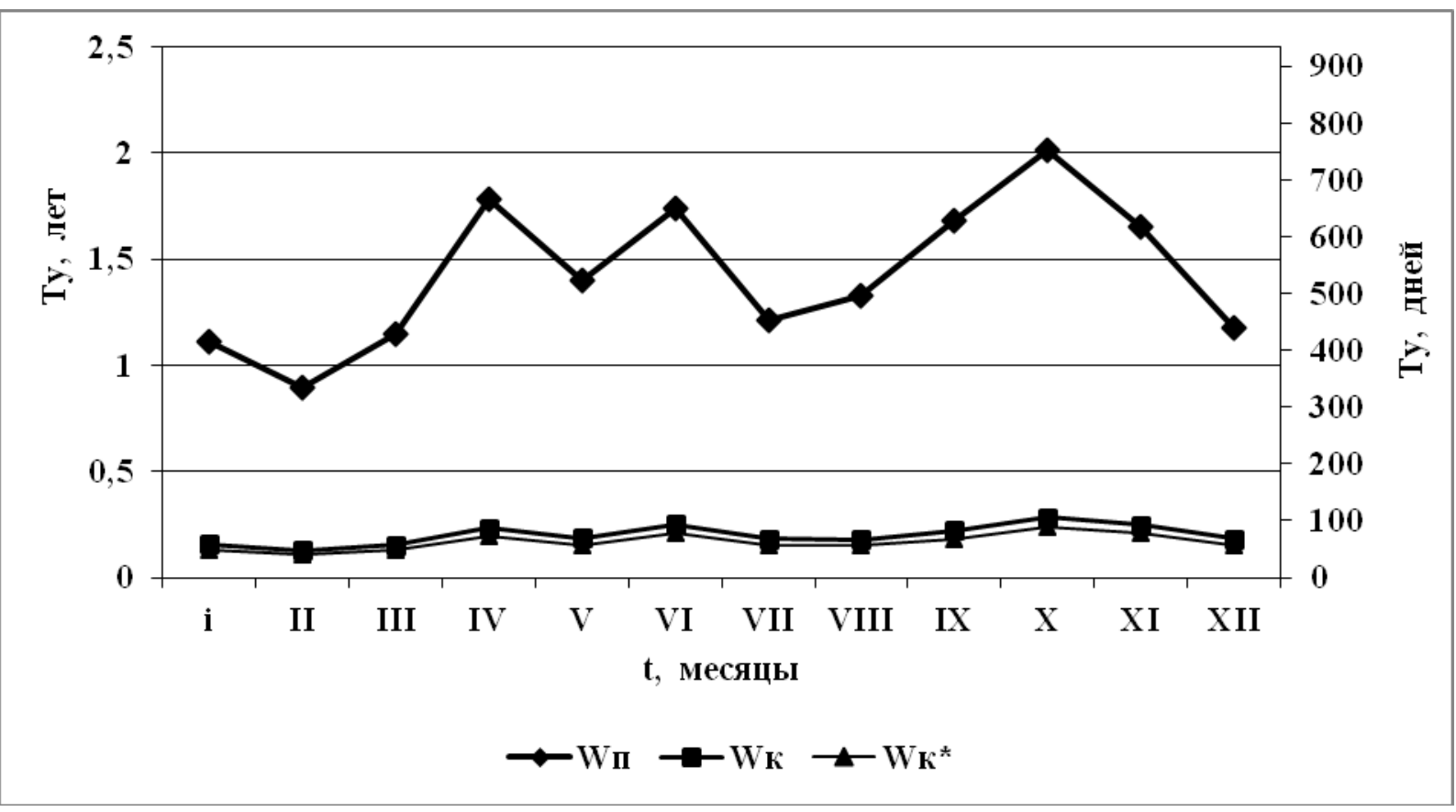

Рис. 5. График $\mathrm{Ty}=\mathrm{f}(\mathrm{t})$ показателей внешнего водообмена в Среднеднепровском водохранилище в проектных и современных параметрах в очень маловодном 2015 году.

Fig. 5. Chart $\mathrm{Tu}=\mathrm{f}(\mathrm{t})$ indicators of external water exchange in the Middlednieper reservoir in design and modern parameters in very low water 2015. 
В табл.1 приведены сравнительные характеристики коэффициентов интенсивности Кв и показатели внешнего водообмена Ту с постепенным учетом всех составляющих водного баланса водохранилищ: Кв 1 - учитывает только основной приток и сток через гидроузел; Кв 2 - учитывает еще боковую приточность и перекачку; Кв учитывает осадки и испарение с водохранилища; Кв4 - учитывает сумму приходных и расходных составляющих водного баланса. Показатели внешнего водообмена Ту во временных единицах - величина, обратная соответствующим коэффициентам интенсивности Кв, которые определяются как отношение суммы притока и расхода воды из водохранилища к удвоенному среднему объему за расчетный период.

Отметим, что коэффициент интенсивности внешнего водообмена Кв с увеличением в расчетах числа составляющих водного баланса возрастает для всех месяцев, характерных по водности лет эксплуатации водохранилища, а показатель внешнего водообмена Ту снижается.

Для заполненного Wп Среднеднепровского водохранилища максимальные коэффициенты интенсивности внешнего водообмена в многоводном (1970) году наблюдаются в мае $\mathrm{K}_{\mathrm{B}_{1}}=6,677, \mathrm{~K}_{2}=6,766, \mathrm{~K}_{3}=6,785, \mathrm{~K}_{4}=6,787$; минимальные в августе - Кв $1=1,034, \mathrm{~K}_{2}=1,051$, $\mathrm{K}_{3}=1,078, \mathrm{~K}_{4}=1,080$.

Соответствующие показатели внешнего водообмена в мае для всех факторов равны Ту $=0,15$ лет, а в августе - Ту $=0,97 ; 0,95 ; 0,93$; 0,93 лет (рис.1,3).

Влияние бокового притока в 1970 году наибольшее $(7,44 \%)$ в марте, а наименьшее $(1,12 \%)$ - в июне. Осадки и испарение оказывали максимальное влияние (более $2,4 \%$ ) на интенсивность внешнего водообмена в августе, минимальное ( $0,06 \%)$ - в апреле. Влияние суммарных составляющих водного баланса Кв4 на внешний водообмен мало отличаются от влияния Квз

Для полезного объема Wк Среднеднепровского водохранилища максимальные коэффициенты интенсивности внешнего водообмена в многоводном (1970) году наблюдаются в апреле $-K_{B_{1}}=33,407, K_{B_{2}}=35,999, K_{\mathrm{B}_{3}}=36,022$, $\mathrm{K}_{4}=36,033 ;$ минимальные в августе $\mathrm{K}_{1}=9,076, \kappa_{B_{2}}=9,225, \kappa_{\mathrm{B}_{3}}=9,462, \mathrm{~K}_{4}=9,480$.

Соответствующие показатели внешнего водообмена в апреле для всех факторов равны
Ту $=0,030-0,028$ лет, а в августе - Ту $=0,110$; 0,$108 ; 0,106 ; 0,105$ лет (табл 1 , рис. 2, 3).

Влияние бокового притока, осадков и испарения, суммарных составляющих водного баланса на интенсивность внешнего водообмена в полезном объеме в 1970 году аналогично заполненному водохранилищу.

Для маловодного (1972) года для заполненного Wп Среднеднепровского водохранилища соответствующие максимальные коэффициенты интенсивности внешнего водообмена наблюдаются в январе и равны: Кв $1=2,164 ; K_{B_{2}}=2,183$; $\mathrm{K}_{3}=2,185 ; \kappa_{B_{4}}=2,187 ;$ минимальные в марте: $\mathrm{K}_{\mathrm{B}_{1}}=0,628 ; \mathrm{K}_{\mathrm{B}_{2}}=0,645 ; \mathrm{K}_{3}=0,651 ; \mathrm{K}_{\mathrm{B}_{4}}=0,653$.

Соответствующие показатели внешнего водообмена в январе для всех факторов равны Ту $=0,46$ лет, а в марте Ту $=1,59 ; 1,55 ; 1,53$; $1,53$ лет (рис. 1,4$)$.

Для полезного объема Wк Среднеднепровского водохранилища соответствующие максимальные коэффициенты интенсивности внешнего водообмена в маловодном (1972) году наблюдаются в январе и равны: Кв $1=11,345 ; \mathrm{K}_{2}=11,444$; $\mathrm{K}_{3}=11,455 ; K_{B_{4}}=11,465$; минимальные в марте: $\mathrm{K}_{\mathrm{B}_{1}}=4,009 ; \mathrm{K}_{\mathrm{B}_{2}}=4,118 ; \mathrm{K}_{\mathrm{B}_{3}}=4,156 ; \mathrm{K}_{\mathrm{B}_{4}}=4,169$. Соответствующие показатели внешнего водообмена в январе для всех факторов равны Ту $=0,088-0,087$ лет, а в марте Ту $=0,249 ; 0,243$; 0,$241 ; 0,240$ лет (табл. 1, рис. 2, 4).

Влияние бокового притока, осадков и испарения, суммарных составляющих водного баланса на интенсивность внешнего водообмена в полезном объеме в 1972 году аналогично заполненному водохранилищу.

Для очень маловодного 2015 года для заполненного Wп Среднеднепровского водохранилища максимальные коэффициенты интенсивности внешнего водообмена наблюдаются в феврале и равны: $\mathrm{K}_{1}=1,074 ; \mathrm{K}_{2}=1,105 ; \mathrm{K}_{3}=1,111$; $\mathrm{K}_{4}=1,117$; минимальные - в октябре: $\mathrm{K}_{\mathrm{B}_{1}}=0,468 ; \kappa_{\mathrm{B}_{2}}=0,481 ; \mathrm{K}_{3}=0,491 ; \kappa_{\mathrm{B}_{4}}=0,497$. Соответствующие показатели внешнего водообмена в феврале для всех факторов равны Ту $=0,931 ; 0,905 ; 0,900 ; 0,895$ лет, а в октябре Ту $=2,14 ; 2,08 ; 2,04 ; 2,01$ лет (рис. 1,5 ).

Для проектного полезного объема Wк Среднеднепровского водохранилища соответствующие максимальные коэффициенты интенсивности внешнего водообмена в очень маловодном (2015) году наблюдаются в феврале и равны: $\kappa_{\mathrm{B}_{1}}=7,564 ; \mathrm{K}_{2}=7,783 ; \kappa_{\mathrm{B}_{3}}=7,825 ; \kappa_{\mathrm{B}_{4}}=7,867$; 
минимальные в октябре: $\mathrm{K}_{1}=3,342 ; \mathrm{K}_{2}=3,434$; $\mathrm{K}_{3}=3,506 ; \mathrm{K}_{4}=3,548$. Соответствующие показатели внешнего водообмена в феврале для всех факторов равны Ту $=0,132 ; 0,128 ; 0,128 ; 0,127$ лет, а в октябре Ту $=0,299 ; 0,291 ; 0,285 ; 0,282$ лет (табл. 1, рис. 2, 5).

Для современного полезного объема $\mathrm{WK}^{*}$ Среднеднепровского водохранилища соответствующие максимальные коэффициенты интенсивности внешнего водообмена в очень маловодном (2015) году наблюдаются в феврале и равны: $\mathrm{K}_{\mathrm{B}_{1}}=9,077 ; \mathrm{K}_{2}=9,340 ; \mathrm{K}_{3}=9,390 ; \mathrm{K}_{4}=9,441$; минимальные в октябре: $\mathrm{K}_{1}=4,010 ; \mathrm{K}_{2}=4,121$; $\mathrm{K}_{3}=4,207 ; \mathrm{K}_{4}=4,258$. Соответствующие показатели внешнего водообмена в феврале для всех факторов равны Ту $=0,110 ; 0,107 ; 0,106 ; 0,106$ лет, а в октябре Ту $=0,249 ; 0,243 ; 0,238 ; 0,235$ лет (табл. 1, рис. 5).

Влияние бокового притока, осадков и испарения, суммарных составляющих водного баланса на интенсивность внешнего водообмена в проектном и современном полезном объеме в 2015 году аналогично заполненному водохранилищу.

Сопоставляя показатели интенсивности внешнего водообмена в полезном объеме и в заполненном Среднеднепровском водохранилище в многоводном и маловодных годах его эксплуатации (рис. 1, 2) отметим заметное расхождение кривых $\mathrm{Ty}=\mathrm{f}(\mathrm{t})$ с марта по июль и с сентября по декабрь.

Показатели внешнего водообмена в единицах времени в годовом аспекте для заполненного Среднеднепровского водохранилища в многоводном 1970 г. равны 0,031 и 0,0046 лет для его полезного объема, в маловодном 1972 г., соответственно, 0,072 и 0,0098 лет, а в очень маловодном 2015 г. - 0,113 лет или 41 день для заполненного водохранилища, 0,0158 лет или 6 дней для его проектного полезного объема Wк и 0,0131 лет или 5 дней для его современного полезного объема $\mathrm{WK}^{*}$.

Для сравнения показатели внешнего водообмена заполненных водохранилищ для многоводного 1970 года на Киевском - равен 0,062 лет, Кременчугском - 0,13 лет, Днепровском - 0,039 лет, Каховском - 0,21 лет, для маловодного 1972 года на Киевском - 0,135, Кременчугском - 0,29, Днепровском - 0,099, Каховском - 0,59 лет, а для очень маловодного 2015 года - на Киевском 0,203, Каневском - 0,117, Кременчугском - 0,502,
Днепровском - 0,144, Каховском - 0,770 лет.

Выводы. 1. Из шести водохранилищ Днепровского каскада Среднеднепровское имеет самую высокую интенсивность внешнего водообмена в пределах многоводного и маловодних годов в заполненном и в полезном объеме водохранилища.

2. При сопоставлении максимальних показателей внешнего водообмена в заполненном и в полезном объеме водохранилища в апреле многоводного года улучшение водообмена в полезном объеме составило $81,3 \%$, в январе маловодного года $-81 \%$, в феврале очень маловодного года (в проектных параметрах водохранилища) $85,8 \%$, а при сопоставлении минимальных показателей по соответствующим годам улучшение водообмена составило в августе - $88,7 \%$, в марте $-84,3 \%$, в октябре $-86 \%$.

3. При сопоставлении показателей внешнего водообмена в полезном объеме водохранилища в проектних и современных его параметрах улучшение водообмена составило $16,6 \%$.

4. Влияние бокового притока, осадков и испарения, суммарных составляющих водного баланса на интенсивность внешнего водообмена в заполненном и полезном объеме в рассматриваемые годы аналогично заполненному водохранилищу.

1. Вишневський В., Шевчук С., Шевченко I. Сучасні розміри дніпровських водосховищ. Водне господарство України. 2017. № 4. С. 23-29.

2. Кліш В.А. Середньодніпровській ГЕС - 55. Гідроенергетика України. 2018. № 3-4. С. 8-9.

3. Обухов E.В. Внешний водообмен Днепровского каскада водохранилищ. Монография. Одесса. Полиграф. 2017. $100 \mathrm{c}$.

4. Яиык А. В., Шмаков В. М. Гидроэкология. К. Урожай. 1992. 192 c.

\section{REFERENCES}

1. Vishnevsky V., Shevchuk C., Shevchenko I. Suchasni rozmiry dniprovskikh vodoskhovishch. [Modern sizes of Dnieper reservoirs]. Water economy of Ukraine. 2017. No. 4. Pp. 23-29. [in Ukraine].

2. Klishch V.A. Serednodniprovskiyi GES - 55. [Middlednieper hydroelectric - 55]. Hidroenergetica Ukrainy. [Hydropower in Ukraine]. 2018. No. 3-4. Pp. 8-9. [in Ukraine].

3. Obukhov E.V. Vneshniy vodoobmen Dneprovskogo kaskada vodokhranilishch. [External water exchange of the Dnieper cascade reservoirs]. Odessa. Poligraf. 2017. 100 p. [in Russian].

4. Yatsyk A.V., Shmakov V.M. Hidroeecologiya. [Hydroecology]. K. Urozhai. [Harvest]. 1992. 192 p. [in Russian]. 


\section{ЗОВНІШНІЙ ВОДООБМІН В КОРИСНОМУ ОБ'СМІ СЕРЕДНЬОДНІПРОВСЬКОГО ВОДОСХОВИЩА В ПРОЕКТНИХ ТА СУЧАСНИХ ЙОГО ПАРАМЕТРАХ}

С.В. Обухов, докт. екон. наук, канд. техн. наук, професор, акад. МАНЕБ, УВ (Одеса)

65039, вул. Середньофонтанська, 30а, м. Одеса, Україна.

Проблемою водосховищ в даний час є їх функиіонування в умовах мінливого клімату. Управління водними ресурсами водних об'єктів, оиінка їх стану і процесів які відбуваються в них, вимагають постійного моніторингу та аналізу. Мета роботи автора - дослідження інтенсивності зовнішнього водообміну на Середньодніпровському (Дніпродзержсинському) водосховищі, його горизонтальної та вертикальної складових, а також господарського використання об'єкта. На основі водобалансовых складових досліджено інтенсивність зовнішнього водообміну в корисному об'ємі водосховища в проектних і сучасних його параметрах з урахуванням водності року за весь період його експлуатаиії: багатовод- ний 1970 р., маловодний 1972 р. і дуже маловодний 2015 p. Визначено коефіиієнти інтенсивності і показники зовнішнього водообміну по кожному місяџю року, місящі з максимальною і мінімальною інтенсивностями зовнішнього водообміну у часових одинииях і основний фактор впливу на нього - бічна приточность у водосховищі. Максимальна інтенсивність зовнішнього водообміну у водосховищі в дуже маловодному році у весняний та осінній періоди його експлуатаиії погіршилася по відношенню до багатоводного року в чотири рази. Встановлено, щзо чим більше коефіџієнт інтенсивності зовнішнього водообміну, тим менше показник зовнішнього водообміну в часових одиницях $і$ інтенсивніше відбуваються зміна $і$ самоочищення води у водосховищі. Якщзо показник зовнішнього водообміну менше одиниці, то зміна нормативних водних ресурсів водосховища відбуватиметься менше ніж за рік. Результати досліджень можуть бути корисними при розробиі режимів експлуатації водосховища в умовах зміни клімату. Бібл. 4, табл. 1, рис. 5.

Ключові слова: водосховище, водний баланс, водообмін, інтенсивність, коефіцієнт..

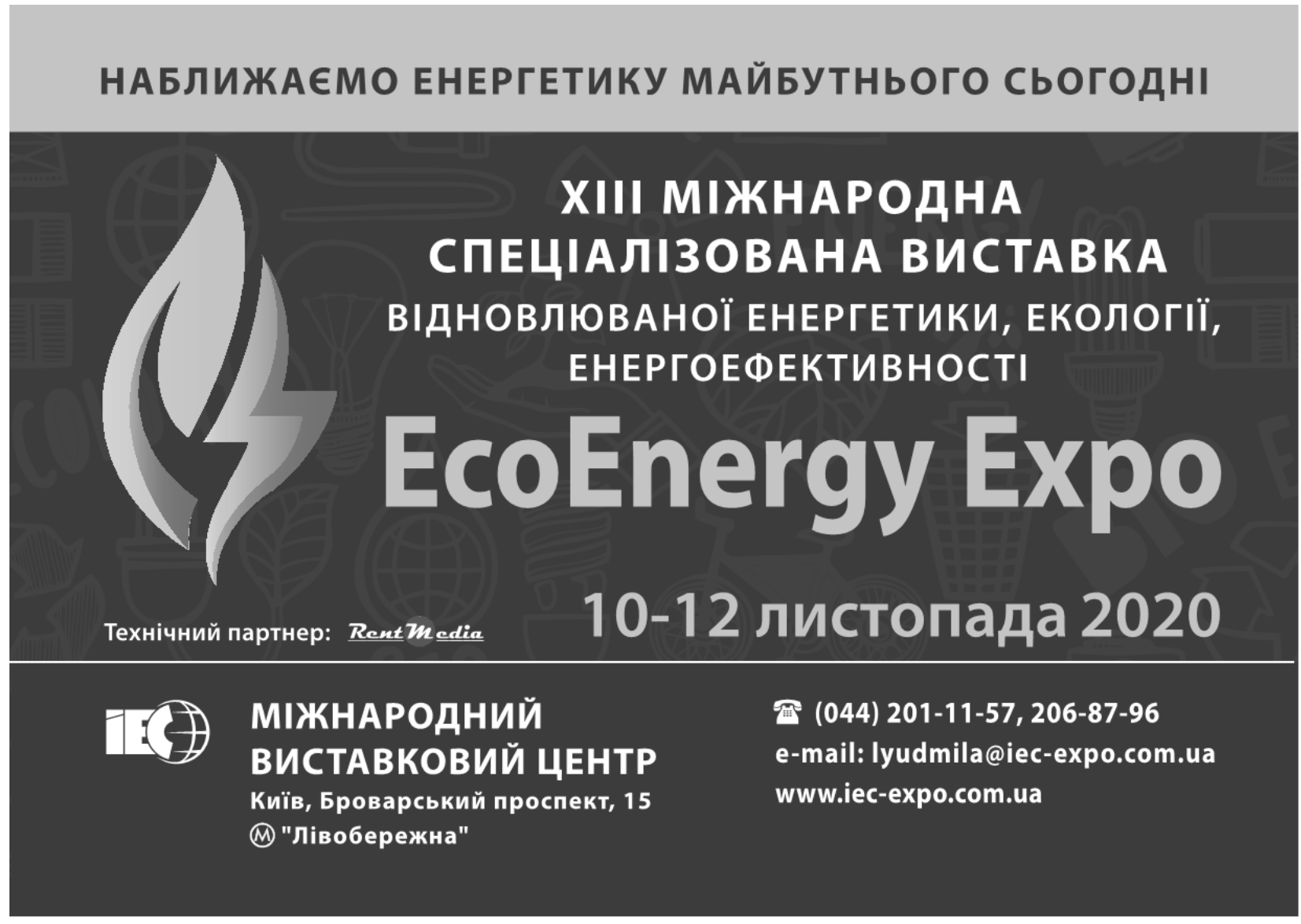

